\title{
Composition, Distribution, and Characterization of Suspected Endocrine-Disrupting Pesticides in Beijing GuanTing Reservoir (GTR)
}

\author{
Nandong Xue, Xiaobai Xu \\ State Key Laboratory of Environmental Chemistry and Ecotoxicology, Research Center for Eco-Environmental Sciences, Chinese Academy of Sciences, \\ 18 Shuangqing Road, Beijing 100085, China
}

Received: 3 May 2005/Accepted: 28 August 2005

\begin{abstract}
GuanTing Reservoir (GTR) is one of two main water resources for the agriculture, industry, and living uses of Beijing (China). As a result of extensive pollution over the last few decades (particularly the 1980s), the reservoir has not supplied potable water to Beijing city since 1997. Composition, distribution, and characterization of 31 suspected endocrine-disrupting pesticides in surface water, pore water, and surface sediments from the reservoir are reported in this study. An analytical procedure based on solid-phase extraction (SPE) technology and capillary gas chromatography with electroncapture detection has been developed for the simultaneous determination of the 31 suspected endocrine-disrupting pesticides including the compounds hexachlorocyclohexane, cyclodiene, diphenyl aliphatic, chlordane, and other selected pesticides (hexachlorobenzene, heptachlor, endrin aldehyde, hepachlor epoxide, dicofol, acetochlor, alachlor, metolachlor, chlorpyriphos, nitrofen, trifluralin, cypermethrin, fenvalerate, and deltamethrin). The result shows that the pesticide pollution is moderate in GTR and its tributaries, although pesticide residue values in a few sites are quite high when considering their endocrine-disrupting effects and chronic health effects. Among the analyzed pesticides, $p, p^{\prime}$-DDE, $o, p^{\prime}$-DDT, $\beta-\mathrm{HCH}$, endosulfan sulfate, and aldrin were the most abundant pesticides in water while $o, p^{\prime}$-DOT, $\delta$ - $\mathrm{HCH}, \beta-\mathrm{HCH}, p, p^{\prime}$-DDE, $p, p^{\prime}$-DDT, and endosulfan sulfate were the most abundant in sediment. The variation in concentration of pesticides among sites can be expected to be caused by several factors such as contaminants in the rivers and drainage of contaminated water from the surrounding agricultural fields. To reduce exposure to these endocrine-disrupting compounds, the abundant current use of pesticides in the area should be minimized. Regular monitoring is needed to manage the environmental hazards due to these pesticides.
\end{abstract}

GuanTing Reservoir (GTR) located northwest of Beijing is one of two main water resources for agriculture, industry, and

Correspondence to: Xiaobai Xu; email: xuxb@public.bta.net.cn living uses of Beijing. Since GuanTing Reservoir has suffered from extensive pollution over the last decades (particularly in the 1980s) due to runoff from non-point sources, direct dumping of waste into rivers, and pollutants carried by rivers (Wang et al. 2003; Zhang et al. 2002a), GTR has not been used as a potable water supply for Beijing city since 1997. Particularly, the economy of the coasts of these rivers that flow into GTR is heavily based on agriculture, thus agrochemicals are used intensively to improve crop yields, and some pesticides have been used heavily in the areas in the past or at the present.

Due to the potential health effects of endocrine disrupters including reproductive disorders, cancer, and impaired development (Hileman 1994; Colborn and Smolen 1996; Turusov et al. 2002; Zhou et al. 2004), trace endocrine-disrupting pesticides in the water body have attracted extensive interest from environmental scientists and the public. Studies have suggested that some pesticides have been identified as potential or suspected endocrine disrupters (Kelce et al. 1995; Zhan et al. 2000; Ren and Jiang 2001; Hemmer et al. 2001). There may be high concentrations exposed to drinking water. The tributaries of GTR flow through an agricultural area where agrochemicals are used intensively to improve crop yields. Many pesticides have been used extensively in these areas since the late 1940s. Therefore, some endocrine-disrupting pesticides are present in the area as persistent residues of previous use, and many of the pesticides are still currently used. Pesticides can not only be concentrated in the environment through biogeochemical processes, but also can also be scavenged from the water through sorption onto suspended material and them deposited to become a part of the bottom substrate. The sediment component of aquatic ecosystems can be sunk for pesticides. Consequently, the bottom sediments often become reservoirs of pesticides in the environment (Khan 1977; Chau and Afgan 1982). Unfortunately, although some studies have assessed the environmental quality of GTR based on persistent organic pollutants (POPs) (Wang et al. 2003), data on endocrine-disrupting pesticide residues in surface sediments are very scarce. Many studies are available that detail methods to examine pesticide multi-residues in food (such as honey, milk, beef, fish, and eggs) and environments, and the analytical methods are fairly well established (Albero et al. 2001; Bergamaschi et al. 1999; Bordet et al. 2002; 


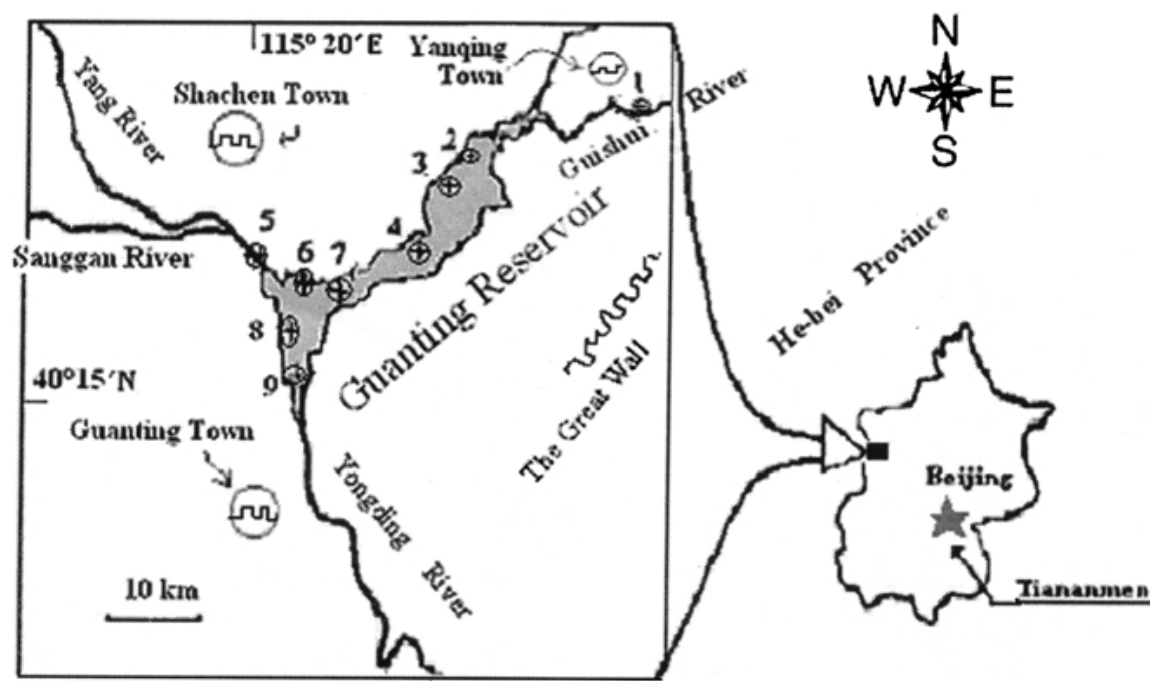

(1, 2, 3, 4, 5, 6, 7,8 and 9 denote nine sanpling sites)

1 YanQing $\left(40^{\circ} 277^{\prime \prime} \mathrm{N}, 115^{\circ} 59^{\prime} 34^{\prime \prime} \mathrm{E}\right)$

2 LaoHnailai $\left(40^{\circ} 21^{\prime} 41^{\prime} \mathrm{N}, 115^{\circ} 45^{\prime} 39^{\prime \prime} \mathrm{E}\right)$

3 GuiDaQino $\left(40^{\circ} 20^{\prime} 41^{\prime \prime}\right.$ N. 115 $\left.42^{\prime} 52^{\prime \prime} \mathrm{E}\right)$

4 QingshuiWang $\left(40^{\circ} 18^{\circ} 03^{\prime} \mathrm{N}, 115^{\circ} 35^{\circ} 08^{\prime} \mathrm{E}\right)$

5 BnoHnoQiao $\left(40^{\circ} 18^{\circ} 03^{\prime \prime} \mathrm{N}, 115^{\circ} 35^{\circ} 08^{\prime \prime} \mathrm{E}\right)$
6 YangHeKou $\left(40^{\circ} 18^{\circ} 02^{\prime \prime} \mathrm{N}, 115^{\circ} 3737 \% \mathrm{E}\right)$

7 ErDaoJinn $\left(40^{\circ} 16^{\prime} 51^{\prime \prime} \mathrm{N}, 115^{\circ} 36^{\prime 0} 08^{\prime \prime} \mathrm{E}\right)$

8 1008Hao $\left(40^{\circ} 16^{\prime 0} 08^{\prime \prime} \mathrm{N}, 115^{\circ} 35^{\prime \prime} 21^{\prime \prime} \mathrm{E}\right)$

9 BaQian $\left(40^{\circ} 15^{\prime} 07^{\prime} \mathrm{N}, 115^{\circ} 36^{\prime} 00^{\prime \prime} \mathrm{E}\right)$
Fig. 1. Sampling sites in GuanTing Reservoir (GTR) and its geographical location
Colume et al. 2001; Snyder et al. 1992; Wan et al. 1994; Zhang et al. 2004). Several methods have been developed and applied for aqueous sample preparation, chromatographic separation, and detection. Common preconcentrations of water samples include liquid-liquid extraction (LLE) (US EPA 1984; Tan 1992), solid phase microextraction (SPME) (Aguilar et al. 1998; Boyd-Boland et al. 1996; Magdic and Pawliszyn 1996), supercritical fluids extraction (SFE) (Nerin et al. 1998; Fatoki and Awofolu 2003), and solid-phase extraction (SPE) (Chris et al. 1990; Lacorte et al. 1993; Albanis and Hela 1995; Crescenzi et al. 1997; Quayle et al. 1997). SPE is described to provide cleaner extracts, less solvent handling, and equivalent or better recoveries than conventional solvent extraction techniques, and thus SPE techniques for the extraction of pesticide multi-residues from aquatic systems have attracted considerable attention and are widely reported in the literature (Chris et al. 1990; Lacorte et al. 1993; Albanis and the 1995; Crescenzi et al. 1997; Nogueira et al. 2004). The use of gas chromatography (GC) with electron capture detection (ECD) for the detection of pesticide multi-residues is common because of its high resolution and good sensitivity in the nanogram range (Tan 1992; Codex Alimentarius 1993; Tolosa et al. 1996; Quayle et al. 1997; Vassilakis et al. 1998; Fatoki and Awofolu 2003). Other advantages of this detector include reduced cost of operation and the fact that it requires less technical skill to obtain reliable results. However, gas chromatography-mass spectrometry (GC-MS) is also widely employed for the determination or confirmation of pesticide multi-residues in complex matrices (Kobayashi et al. 1993; Albanis et al. 1998; Bergamaschi et al. 1999; Fatoki and Awofolu 2003).

The goal of this study is to develop a method of multi-class pesticide analysis and to investigate the composition, distribution, and characterization of multi-class suspected endocrine-disrupting pesticides in surface water, pore water, sand surface sediments from the reservoir in order to understand and assess the status of contamination and to identify the factors that may control the pesticides in the area.

\section{Materials and Methods}

\section{Sampling Locations}

Samples were collected from nine locations in GTR in September and November 2003, and in May and August 2004. The locations of the nine sampling sites in the reservoir are shown in Figure 1. The sites were chosen based on hotspots of pollution around GTR such as industrial regions, domestic wastewater discharge areas, or the entrances of rivers. Throughout the survey, a global positioning system (GPS) was used to identify each sampling location precisely. The top sediment samples (a mixture of sediment from the upper $10 \mathrm{~cm}$ ) were collected by a grab sampler (Wildlife Supply Company, Saginaw, MI) in nine sampling sites. Samples were homogenized on site in clean glass containers after removing pebbles and twigs. All samples were immediately sealed and stored at $-20^{\circ} \mathrm{C}$ in pre-cleaned glass jars until analysis. Surface water samples were collected at the same sites. Samples were taken using pre-cleaned glass bottles held in a weighted stainless-steel frame fitted with a spring-loaded PTFE (polytetrafluoroethylene) stopper with a subsurface trigger to avoid sampling the surface micro-layer.

Table 1 provides the basic physicochemical parameters of sediment samples collected from the GTR. The depth of the water column above the sediment layer was between 8.5 and $1.2 \mathrm{~m}$. The water content of sediments ranged from $36.1 \%$ to $71.5 \%$. The organic matter (denoted by loss on ignition, LOI\%) of sediments ranged from $3.98 \%$ to $8.49 \%$. The maximum organic matter of the sediment samples was observed at sampling site 7, which is located in front of a dam. $\mathrm{pH}$ values of sediments ranged from 7.91 to 8.52 with an average of 8.06. Clay and silt content $(\%)$ denote the texture of sediment samples. The maximum value of the sum of clay $(\%)$ and silt $(\%)$ was the sample from site 9 
Table 1. The basic physicochemical properties of natural surface sediment samples collected from GuanTing reservoir (GTR)

\begin{tabular}{|c|c|c|c|c|c|c|}
\hline Sampling sites & Water depth (m) & Water content $(\%)$ & Loss on Ignition (LOI, \%) & $\mathrm{pH}$ & Clay $(\%)$ & Silt $(\%)$ \\
\hline 1 & 1.2 & 40.0 & 7.13 & 7.97 & 24.8 & 52.1 \\
\hline 2 & 1.5 & 42.8 & 4.58 & 8.12 & 18.5 & 37.7 \\
\hline 3 & 1.5 & 69.7 & 3.98 & 8.52 & 8.9 & 28.2 \\
\hline 4 & 1.5 & 59.2 & 5.59 & 8.03 & 19.8 & 37.4 \\
\hline 5 & 1.2 & 41.6 & 6.72 & 7.85 & 22.4 & 47.5 \\
\hline 6 & 4.2 & 36.1 & 5.74 & 7.95 & 20.3 & 44.6 \\
\hline 7 & 5.5 & 51.2 & 5.03 & 8.01 & 18.6 & 38.0 \\
\hline 8 & 5.8 & 64.8 & 6.81 & 7.92 & 21.4 & 39.8 \\
\hline 9 & 8.5 & 71.5 & 8.49 & 7.91 & 30.4 & 57.5 \\
\hline
\end{tabular}

(87.9\%). The physicochemical properties of water samples were also analyzed. The range of $\mathrm{COD}_{\mathrm{cr}}$ (Chemical Oxygen Demand by Bichromade) in water samples was between 3.5 and $18.5 \mathrm{mg} / 1$. The maximum value of $\mathrm{COD}_{\mathrm{cr}}$ was at site 9 and the minimum was at site 3 .

\section{Chemicals and Materials}

Residue analysis-grade n-hexane, acetone, dichloromethane (DCM), and ethyl acetate (Merck, Darmstadt, Germany), chromatography grade acetonitrile (ACN), and methonol (Tianjing chemical plant, China) were used for sample processing and extraction.

Anhydrous sulfate sodium was supplied by Liu-Li Chemical Plant (Beijing, China) and treated at $140^{\circ} \mathrm{C}$ for $24 \mathrm{~h}$ before using. Deionized water was purified with an ultra-pure water system (Beijing Li- Yuan Electronic Let, China). Some pesticide standards $(\alpha-\mathrm{HCH}$, $\beta-\mathrm{HCH}, \gamma-\mathrm{HCH}, \delta-\mathrm{HCH}, \mathrm{HCB}$, aldrin, heptachlor, endosulfan, $p, p^{\prime}-$ DDD, $o, p^{\prime}$-DDT, endrin aldehyde, endosulfan sulfate, $p, p^{\prime}$-DDT, $p, p^{\prime}$ DDE, methoxychlor, hepachlor epoxide [HEPO], chlordane, dieldrin endrin) and internal standard (IS, 2,4,5,6-tetrachloro-m-xylene) used in this study from Dr. Ehrensdorfer (Augsburg, Germany) and were purchased from $\mathrm{J} \& \mathrm{~K}$ Chemical Ltd. Other pesticide standards (dicofol, acetochlor, alachlor, metolachlor, chlorpyriphos, nitrofen, trifluralin, cypermethrin, fenvalerate, deltamethrin) used in this study from the Institute of Agricultural Environment Protection (Tianjing, China) were purchased from Yin TianYi standard Ltd. The purity of all selected compounds was $>95 \%$. Standard solutions of pesticides were prepared in acetone or alcohol and stored in a freezer at $-20^{\circ} \mathrm{C}$. The stock standard solution of each pesticide was $2 \mathrm{mg} / \mathrm{l}$. Intermediate standard solutions were prepared by dilution in acetone and subsequently dilution was made for GC analyses in the range $0.01-1.0 \mathrm{ng} /$ ml. Florisil (60-100 mesh) was obtained from Supelco, Inc. (Bellefonte, PA) and was used as sorbents in the clean-up columns. Florisil was activated at $130^{\circ} \mathrm{C}$ for $12 \mathrm{~h}$ and partially deactivated with $0.5 \%$ water prior to use. The columns were protected against water by adding a $1-\mathrm{cm}$ layer of anhydrous sodium sulfate (Liu-Li Chemical Plant, Beijing) on top of the sorbent (8 g of Florisil). The Oasis ${ }^{\circledR}$ HLB cartridge $(6 \mathrm{cc}, 500 \mathrm{mg})$ was purchased from Waters Corp. (Milford, MA), and Visiprep ${ }^{\mathrm{TM}}$-DL SPE Vacuum Manifold with disposable flow control valve liners, a SPE system, from Supelco, Inc. (Bellefonte, PA).

All glassware was treated with a sulfochromic mixture at first and then washed with different solvents in the order of water, acetone, and n-hexane prior to use.

\section{Analytical Procedures}

Water samples collected from GTR were pre-filtered using $0.45-\mu \mathrm{m}$ PTFE fiber-glass filters (Millipore, Bedford, MA) under vacuum after returning to the laboratory within one or two days to obtain dissolved samples and suspended particulate matter (SPM) samples. Up to $1.0 \mathrm{~L}$ of the dissolved water samples was extracted by SPE following the revised method after Nogueira et al. (2004). An internal standard (IS) was added to each water sample $(50 \mathrm{ng} / 1)$. Each of the Oasis ${ }^{\circledR}$ HLB cartridges was conditioned with $5 \mathrm{ml}$ of methanol/ACN (50/50, $\mathrm{v} / \mathrm{v}), 5 \mathrm{ml}$ of methanol, and $5 \mathrm{ml}$ of ultra-pure water and slowly aspirated $(-0.2$ bar). Water samples were passed through the car-

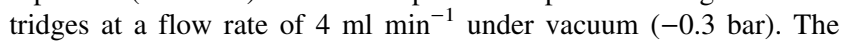
column was washed with $2 \times 3 \mathrm{ml}$ of ultra-pure water, followed by vacuum drying for $5 \mathrm{~min}$. Subsequently, the elution took place with $3 \times 4 \mathrm{ml}$ of methanol/ACN $(50 / 50, \mathrm{v} / \mathrm{v})$. After water was removed from the extracts by anhydrous $\mathrm{Na}_{2} \mathrm{SO}_{4}$, the extract was reduced in volume to dryness under a gentle stream of nitrogen in a water bath. The dry residues obtained were re-dissolved in $0.5 \mathrm{ml}$ of acetone for GC determination, For blank assays, the same procedure as above was performed using water samples with an IS spiked.

After returning to the laboratory, routine wet sediment sample analyses were done as follows: the water content was determined by drying about $5.0 \mathrm{~g}$ of wet sediments for $12 \mathrm{~h}$ (or to constant weight) at $105^{\circ} \mathrm{C}$. The dried sediment was heated at $550^{\circ} \mathrm{C}$ for $1 \mathrm{~h}$ in order to determine the organic matter (Golterman et al. 1983; Hakanson and Jansson 1983). Silt and clay analyses of sediment samples were done by a pipette analysis method (Carver 1971). $\mathrm{pH}$ values were determinated by a $\mathrm{pH}$ meter (pHs-2, Shanghai 2nd Analytical Instrument Factory, China). Each sediment sample was centrifuged (4000 rpm, Q/1BL001-94, Beijing Centrifuge Instrument Factory, China) at $4^{\circ} \mathrm{C}$ to obtain pore water in sediment. After being prefiltered using 0.45 $\mu \mathrm{m}$ PTFE fibre-glass filters, the pore water $(300 \mathrm{ml})$ was extracted and analyzed using the same procedure as described for water samples. Ten grams (wet weight) of the centrifuged sediments were weighed to determine water content. Another $20 \mathrm{~g}$ (wet weight) of the centrifuged sediments (spiked with IS to quantify the overall recovery of the procedures) were weighed into a glass vial and sonicated for 30 min with $2 \times 40 \mathrm{ml}$ of methanol/ACN $(50 / 50, \mathrm{v} / \mathrm{v})$ in an ultrasonic bath (Institute of Acoustics, CAS, China). Extracts were transferred into glass flasks by careful decantation. The extracts were evaporated to about $25 \mathrm{ml}$ under vacuum with a rotavapor (Büchi, Flawil, Switzerland) in a water bath (about $80^{\circ} \mathrm{C}$ ). The concentrated extracts were re-extracted with hexane-ether $(6: 94,15: 85,50: 50, \mathrm{v}: \mathrm{v})$ three times, with 10-ml quantities each time, The organic phase was evaporated to near dryness. The residues were cleaned up by a Florosil column $(8 \mathrm{~mm}$ i.d. $\times 350 \mathrm{~mm})$. Anhydrous sodium sulfate $(2$ $\mathrm{cm}$ ) was added on the top of the column in order to remove water. The column was then eluted first with $4 \mathrm{ml}$ of DCM/n-hexane $(20 / 80$, $\mathrm{v} / \mathrm{v}$ ) and the solution discarded. A further $25 \mathrm{ml}$ of DCM/n-hexane $(20 / 80, v / v)$ was needed to elute to obtain pesticides. After collection, the eluate was evaporated near dryness under a nitrogen flow. Subsequently, the sample was dissolved in $1 \mathrm{ml}$ of acetone for GC determination. SPM samples were extracted using the same procedure sediment samples described above.

Determination was done by a GC system with a micro-cell electron capture detector ( $\mu$-ECD) and split/splitless injector (Agilent Series 
6890), equipped with ChemStation Software. A fused silica capillary column (HP-5, $30 \mathrm{~m} \times 0.25-\mu \mathrm{m}$ i. d., and $0.25-\mu \mathrm{m}$ film thickness) was used. The oven temperature has been programmed as follows; $80^{\circ} \mathrm{C}$ for $1 \mathrm{~min}$, ramped at $10^{\circ} \mathrm{C} \mathrm{m^{-1 }}$ to $150^{\circ} \mathrm{C}$, held for $2 \mathrm{~min}$, and then ramped at $2^{\circ} \mathrm{C} \min ^{-1}$ to $180^{\circ} \mathrm{C}$ and held for $1 \mathrm{~min}$, then rising to $250^{\circ} \mathrm{C}$ at a rate of $5^{\circ} \mathrm{C} \mathrm{min}^{-1}$ and held for $1 \mathrm{~min}$. The final temperature was $290^{\circ} \mathrm{C}$ held for $5 \mathrm{~min}$, with a total run of $50 \mathrm{~min}$. The carrier gas was high purity nitrogen gas, with a flow of $0.8 \mathrm{ml} \mathrm{min}^{-1}\left(160^{\circ} \mathrm{C}\right)$ and a column head pressure of $1.02 \mathrm{~atm}$. A split/splitless injector with a 2$\mathrm{mm}$ i.d. glass liner was used in the splitless mode for 1 min. Injector temperature was $230^{\circ} \mathrm{C}$ and split flow was $24 \mathrm{ml} \mathrm{min}^{-1}$ until the end of analysis; the injection volume was of $1 \mu \mathrm{l}$. The electron capture detector temperature was kept at $310^{\circ} \mathrm{C}$.

\section{Identification and Quantification}

Before analysis, relevant standards were run to check column performance, peak height, resolution, and the limits of detection (LOD). With each set of samples analyzed, a solvent blank, a standard mixture, and a procedural blank were run in sequence to check for contamination, peak identification, and quantification. None of the target compounds was detected in the procedural blanks for water and sediment. The recovery, LOD, and relative standard deviation (RSD) for water were as follows: LOD of target compounds (include IS) ranged from $5.0 \times$ to $10^{-4}$ to $1.5 \times 10^{-2} \mathrm{ng} / \mathrm{l}$ for water, and $3.0 \times 10^{-5}$ to $1.5 \times 10^{-3} \mathrm{ng} / \mathrm{g}$ for sediment. Three replicates for each sample have been carried out at three fortification levels $(0.5,5.0,50 \mathrm{ng} / \mathrm{g})$, and the relevant recovery results, given as mean values, were $70-103 \%$ and $71-103 \%$ for water and sediment, respectively. RSD was $2.0-7.0 \%$ and $4.0-8.0 \%$ for water and sediment, respectively. The recoveries are satisfactory for all selected compounds. Average recoveries of the IS, 2,4,5,6-tetrachloro-m-xylene, were $97 \%$ and $92 \%$ in water and sediment, respectively.

All data were subject to strict quality-control procedures including the repeatability of GC/ECD determinations through the analysis of procedural blanks and spiked samples $(5.0 \mathrm{ng} / \mathrm{g})$ level. Peak identification was conducted by the accurate retention time of each standard $( \pm 1 \%)$ while quantification was done by comparison of peak areas of samples to those of standards at known concentrations. Identification of those pesticides was confirmed on a number of samples with gas chromatography-mass spectrometry (Agilent 6890 with mass spectrometer 5973 mass selective detector; Agilent Technologies, USA) in selected-ion monitoring mode (SIM). For SIM, three characteristic ions were selected for each compound. Scanned mass range was 40 $600 \mathrm{~m} / \mathrm{z}$. The source temperature was $230^{\circ} \mathrm{C}$. Mass spectra were acquired at electron II impact (EI) mode at $70 \mathrm{eV}$. The capillary column (HP: $35 \mathrm{~ms} ; 30 \mathrm{~m} \times 0.25 \mathrm{~mm}$ i.d., and $0.25-\mu \mathrm{m}$ film thickness) was used. The oven temperature has been programmed: $70^{\circ} \mathrm{C}$ for $2 \mathrm{~min}$, ramped at $25^{\circ} \mathrm{C} \min ^{1}$ to $150^{\circ} \mathrm{C}$, then ramped at $3^{\circ} \mathrm{C} \mathrm{min}{ }^{-1}$ to $200^{\circ} \mathrm{C}$. The final isotherm has been ramped at $8^{\circ} \mathrm{C} \mathrm{min}{ }^{-1}$ to $280^{\circ} \mathrm{C}$ and held for $10 \mathrm{~min}$. Injector temperature was $250^{\circ} \mathrm{C}$; The constant pressure was $20 \mathrm{psi}$ and injection volume was of $2 \mu$ l. Table 2 summarizes acquisition data (retention time and characteristic fragment ions) for pesticides including an internal standard (IS).

\section{Results and Discussion}

\section{Levels of Pesticide Residues in Sediment and Water Samples in the Reservoir}

The analyzed samples showed the presence of pesticides in water and sediment at concentrations above the detection limits of the method (Table 3). No data were obtained in the SPM phase due to the small amount of SPM available in water samples. Therefore, the following discussion presents pesticides in the surface water and the sediments only. Pesticides detected in water and sediments are listed in Table 3 including the compounds hexachlorocyclohexane $(\mathrm{HCH} ; \alpha-\mathrm{HCH}, \beta-$ $\mathrm{HCH}, \gamma-\mathrm{HCH}$, and $\delta-\mathrm{HCH}$ ), cyclodiene (aldrin, dieldrin, endrin, endosulfan I and II, and endosulfan sulfate), diphenyl aliphatic $\left(p, p^{\prime}\right.$-DDD, $o, p^{\prime}$-DDT, $p, p^{\prime}$-DDT, $p, p^{\prime}$-DDT, and methoxychlor), chlordane ( $\alpha$ - and $\gamma-)$, and other selected pesticides (hexachlorobenzene [HCB], heptachlor, endrin aldehyde, HEPO, dicofol, acetochlor, alachlor, metolachlor, chlorpyriphos, nitrofen, trifluralin, cypermethrin, fenvalerate, and deltametlirin). The levels of total OCPs both in water $(17.9-723 \mathrm{ng} / 1$, with a mean of $220 \mathrm{ng} / 1)$ and in sediment (7.17-33.6 ng/g, with a mean of $10.3 \mathrm{ng} / \mathrm{g}$ ) from GTR are lower than that from Beijing Tonghui River (Zhang et al. 2004). However, the level in water is higher than that of several other locations on the east coast of China such as the Jiulong River Estuary (115-414.7 ng/1, with a mean of 191.5 ng/l; Zhang et al. 2002c), Pearl River Estuary (4.44-635 ng/1, with a mean of $88.31 \mathrm{ng} / 1$; Zhang et al. 2002b), and South China Sea (1.27-121.8 ng/1, with a mean of $16.49 \mathrm{ng} / 1$; Zhang et al. 2002b).

The levels of pesticides in sediment samples recorded in this study are compared with those of other countries. HCH concentrations were found to be in the range of $0.24-11.1 \mathrm{ng} / \mathrm{g}$ dry wt (Table 3). Concentrations of $\gamma-\mathrm{HCH}$ (commercial name lindane) in sediment samples $(0.0013-0.22 \mathrm{ng} / \mathrm{g})$ are lower than that reported from the Romanian coastline by Fillmann et al. (2002) and that reported from Indian cities by Sarkar and Sen Gupta (1991) and Iwata et al. (1994). Our results also showed lower mean concentrations of total DDTs in sediments than concentrations found in the coastline and rivers of Turkey (7-71 ng/g) (Bakan et al. 1999), in the Ukranian coastline of the Black Sea in the past (Fillmann et al. 2002), and in Washington, DC (7-160 ng/g) (Wade et al. 1994) but similar mean concentrations to that in cities in Japan $(2.5-12 \mathrm{ng} / \mathrm{g})$ (Iwata et al. 1994). Chlordane ( $\alpha$-chlordane and $\gamma$-chlordane) concentrations $(0.046-0.52 \mathrm{ng} / \mathrm{g})$ were also much lower than those reported from Washington, DC $(5-153 \mathrm{ng} / \mathrm{g}$ ) (Wade et al. 1994). Therefore, the levels of pesticides in GTR and its tributaries are generally lower than those in other countries.

DDE and DDD are two environmental dehydrochlorination products of DDT, a popular insecticide banned from use in 1983 in the studied area. The large volume of DDT previously used, the persistence of DDT, DDE, and DDD, and the high $\mathrm{K}_{\mathrm{oc}}$ (the soil/sediment partition or sorption coefficient) of these compounds account for its frequent detections in sediments. Sediment quality assessment guidelines have been developed for several compounds in sediments (FDEP 1994). The threshold effects level (TEL) is $2.1 \mathrm{ng} / \mathrm{g}$ and the probable effects level (PEL) is $374 \mathrm{ng} / \mathrm{g}$ for DDE in coastal sediments. The $p, p^{\prime}$-DDE concentrations detected $(0.3$ to $6.4 \mathrm{ng} / \mathrm{g})$ are between the TEL and PEL. The levels between the TEL and PEL have the possibility for impacting wildlife as they have exceeded the threshold level. The DDT ( $p, p^{\prime}$-DDT and $o, p^{\prime}$ DDT) concentrations detected (2.5 to $12.2 \mathrm{ng} / \mathrm{g}$ ) are between the TEL (1.2 ng/g) and PEL ( $4.8 \mathrm{ng} / \mathrm{g})$. The levels between the TEL and PEL have the possibility for impacting wildlife as they have exceeded the threshold level. Only the $p, p^{\prime}$-DDD 
Table 2. Acquisition data for GC-MS analysis of pesticides including an internal standard (IS) using a selected-ion monitoring (SIM) mode, three selected ions for each compound, and 10 acquisition windows

\begin{tabular}{|c|c|c|c|c|}
\hline IS and pesticides & $\begin{array}{l}\text { Retention time } \\
(\mathrm{min})\end{array}$ & $\begin{array}{l}\text { Characteristic fragment } \\
\text { ions MS-1 }\end{array}$ & $\begin{array}{l}\text { Characteristic fragment } \\
\text { ions MS-2 }\end{array}$ & $\begin{array}{l}\text { Characteristic fragment } \\
\text { ions MS-3 }\end{array}$ \\
\hline IS & 9.07 & 207 & 209 & 244 \\
\hline Trifluralin & 10.10 & 306 & 219 & 290 \\
\hline$\alpha-\mathrm{HCH}$ & 10.39 & 183 & 219 & 181 \\
\hline Hexachlorobenzene & 10.63 & 284 & 286 & 249 \\
\hline$\beta-\mathrm{HCH}$ & 11.6 & 219 & 183 & 181 \\
\hline$\gamma-\mathrm{HCH}$ & 12.01 & 109 & 219 & 183 \\
\hline Dicofol & 12.53 & 139 & 141 & 251 \\
\hline$\delta-\mathrm{HCH}$ & 13.02 & 191 & 288 & 219 \\
\hline Acetochlor & 14.45 & 146 & 162 & 223 \\
\hline Heptachlor & 14.58 & 100 & 274 & 272 \\
\hline Alachlor & 14.88 & 169 & 188 & 224 \\
\hline Aldrin & 15.07 & 66 & 362 & 263 \\
\hline Metolachlor & 16.64 & 162 & 238 & 240 \\
\hline Chlorpyriphos & 16.85 & 197 & 199 & 201 \\
\hline Heptachlor epoxide & 18.24 & 355 & 351 & 353 \\
\hline$\gamma$-Chlordane & 19.50 & 373 & 375 & 377 \\
\hline Endosulfan I & 20.08 & 207 & 241 & 195 \\
\hline$\alpha$-Chlordane & 20.33 & 373 & 375 & 377 \\
\hline Dieldrin & 21.51 & 79 & 277 & 263 \\
\hline$p, p^{\prime}-\mathrm{DDE}$ & 21.82 & 246 & 318 & 248 \\
\hline Endin & 22.61 & 263 & 279 & 315 \\
\hline Endosulfan II & 23.10 & 207 & 237 & 195 \\
\hline$p, p^{\prime}-\mathrm{DDD}$ & 23.83 & 235 & 318 & 165 \\
\hline$o, p^{\prime}-\mathrm{DDT}$ & 23.91 & 235 & 352 & 165 \\
\hline Endrin aldehyde & 23.99 & 347 & 345 & 250 \\
\hline$p, p^{\prime}-\mathrm{DDT}$ & 24.26 & 235 & 352 & 165 \\
\hline Methoxychlor & 27.36 & 228 & 227 & 207 \\
\hline Cypermethrin & 31.46 & 163 & 206 & 226 \\
\hline Fenvalerate & 32.83 & 125 & 167 & 419 \\
\hline Deltamethrin & 34.21 & 172 & 181 & 415 \\
\hline
\end{tabular}

Ten acquisition windows in SIM mode: 9-11.5 min, 11.5-14.5 min, 14.5-15 min, 15-17 min, 17-19 min, 19-21.5 min, 21.5-22.5 min, 22.5-24 min, 24-28 min, 28-34.5 min.

concentrations varied from below the detection limit to 0.012 $\mathrm{ng} / \mathrm{g}$. These values fall between the TEL (1.2 ng/g) and PEL (7.8 ng/g).

The total DDT (sum of $p, p^{\prime}$-DDE, $p, p^{\prime}$-DDD, $p, p^{\prime}$-DDT, and $o, p^{\prime}$-DDT) and $\gamma-\mathrm{HCH}$ in sediment samples was $0.33-7.4 \mathrm{ng} / \mathrm{g}$ and $0.0013-0.22 \mathrm{ng} / \mathrm{g}$, respectively. Levels of all detected pesticides were below the New York sediment quality criteria and the guidelines to protect wildlife from adverse effects associated with the accumulation of persistent substances in aquatic biota (total DDT 100 and $\gamma$-HCH 1500 ng/g dry wt) (MacDonald 1994). The concentrations of pesticides in water (Table 3) are generally lower than the Chinese standards for surface water (500 ng/1 for organochlorine insecticides) and tap water (500 ng/ 1 for the sum of pesticides and $100 \mathrm{ng} / 1$ for individual pesticide).

Other pesticides considered in this work (metolachlor, trifluralin, nitrofen acetochlor, alachlor, chlorpyriphos, cypermethrin, deltamethrin, and fenvalerate) are compounds frequently used in this region and are associated with health risks as endocrine-disrupting pesticides. However, the data for their residues in water or in sediments were scarce, which can be attributed to their lesser persistence. These currently used pesticides were monitored in river ecosystems (e.g., in Central American) and demonstrated that these substances are also relevant contaminants in the aquatic environment (Castillo et al. 2000; Castilho et al. 2000; Volker Laabs et al. 2002).
The frequencies of detection of metolachlor, deltamethrin, trifluralin, nitrofen, and acetochlor in sediment samples from GTR were $100 \%$. The frequencies of detection in water samples were different as follows: metolachlor (25\%), deltamethrin $(30 \%)$, trifluralin $(75 \%)$, nitrofen $(50 \%)$, and acetochlor $(50 \%)$. High frequencies of detection of those pesticides in sediments and water samples from GTR reflected the abundant current use of them in the area and the river watersheds. These results also suggest that the use of the pesticides in the agricultural system should be minimized.

Total concentrations of metolachlor, trifluralin, nitrofen acetochlor, alachlor, and chlorpyriphos in water samples (in the range of 19.2-42.7 ng/1, with a mean value $29.7 \mathrm{ng} / 1$ ) and in sediment samples (in the range of $0.568-2.93 \mathrm{ng} / \mathrm{g}$, with a mean value $1.59 \mathrm{ng} / \mathrm{g}$ ) are lower than that reported from the Northeastern Pantanal Basin, Brazil, by Laabs et al. (2002), where total concentrations were found in the range of 31-56 $\mathrm{ng} / 1$, with a mean value $55 \mathrm{ng} / \mathrm{l}$. Total concentrations were apparently higher in sediment samples because these pesticides are not found (below detection limits) in the Northeastern Pantanal Basin.

Cypermethrin, deltamethrin, and fenvalerate are in the class of synthetic pyrethroids that have been introduced over the past two decades for a variety of insecticidal uses. Each of these chemicals is highly lipophilic and in aquatic environ- 
Table 3. Range, mean, and standard deviations (SD) of pesticide concentrations in water (ng/l), pore water (ng/l), and sediment (ng/g, dry wt) samples

\begin{tabular}{|c|c|c|c|c|c|c|c|c|c|}
\hline \multirow[b]{2}{*}{ Compounds } & \multicolumn{3}{|c|}{ Water (ng/l) } & \multicolumn{3}{|c|}{ Pore water (ng/l) } & \multicolumn{3}{|l|}{ Sediment (ng/g) } \\
\hline & Range & Mean & SD & Range & Mean & SD & Range & Mean & SD \\
\hline Trifluralin & $3.41-5.15$ & 4.5 & 1.32 & ND-83.6 & 44.0 & 27.2 & $0.120-1.01$ & 0.127 & 0.311 \\
\hline$\alpha-\mathrm{HCH}$ & $1.32-17.8$ & 7.62 & 3.57 & $2.20-66.4$ & 24.8 & 22.6 & $0.0562-0.159$ & 0.149 & 0.0304 \\
\hline $\mathrm{HCB}$ & $1.43-27.3$ & 12.4 & 8.82 & $12.2-58.5$ & 18.9 & 13.0 & $0.0552-0.494$ & 0.146 & 0.115 \\
\hline$\beta-\mathrm{HCH}$ & $12.3-60.5$ & 31.1 & 15.6 & $12.6-79.8$ & 45.6 & 20.6 & $1.53-5.99$ & 1.73 & 1.43 \\
\hline$\gamma-\mathrm{HCH}$ & ND-120 & 31.3 & 22.7 & ND-13.7 & 1.32 & 11.5 & $0.00132-0.140$ & 0.104 & 0.0358 \\
\hline Dicofol & ND-2.60 & 0.91 & 0.82 & ND-28.5 & 4.00 & 8.42 & ND-0.0627 & 0.0487 & 0.0154 \\
\hline$\delta-\mathrm{HCH}$ & $0.39-4.62$ & 1.24 & 0.73 & ND-159 & 44.5 & 62.8 & $0.952-4.67$ & 1.05 & 1.77 \\
\hline Acetochlor & ND-1.50 & 0.55 & 0.41 & ND-26.5 & 9.58 & 4.18 & $0.010-0.188$ & 0.0374 & 0.168 \\
\hline Heptachlor & $0.66-8.50$ & 0.98 & 3.14 & ND-50.8 & 7.2 & 25.4 & 0.0072 & 0.0163 & 0.0308 \\
\hline Alachlor & ND-5.68 & 1.72 & 2.08 & ND-41.2 & 9.1 & 13.0 & ND-0.219 & 0.0872 & 0.0614 \\
\hline Aldrin & $1.65-32.4$ & 23.0 & 8.05 & $132-798$ & 148 & 130.8 & $0.172-1.30$ & 0.472 & 0.429 \\
\hline Metolachlor & $15.5-27.2$ & 22.7 & 5.21 & $42.5-138$ & 45.3 & 29.5 & $0.0658-0.297$ & 0.0742 & 0.145 \\
\hline Chlorpyriphos & $0.30-1.89$ & 1.50 & 0.44 & $1.90-8.77$ & 3.3 & 2.81 & $0.052-0.165$ & 0.0659 & 0.060 \\
\hline HEPO & $0.49-12.0$ & 4.10 & 2.86 & ND-12.9 & 5.12 & 3.45 & $0.0108-0.232$ & 0.0782 & 0.103 \\
\hline$\gamma$-chlordane & $0.53-30.8$ & 7.26 & 12.9 & ND-10.2 & 1.86 & 2.04 & $0.0466-0.398$ & 0.0764 & 0.0781 \\
\hline Endosulfan I & $0.07-13.8$ & 1.48 & 11.9 & $5.05-38.3$ & 16.6 & 7.03 & $0.0151-0.058$ & 0.0385 & 0.0127 \\
\hline$\alpha$-chlordane & $0.31-8.2$ & 2.86 & 1.99 & ND-34.9 & 17.8 & 7.82 & ND-0.144 & 0.0455 & 0.0325 \\
\hline Dieldrin & ND-4.54 & 0.59 & 2.91 & ND-12.9 & 8.52 & 4.04 & $17.2-219$ & 0.0487 & 0.0408 \\
\hline$p, p^{\prime}-\mathrm{DDE}$ & $1.64-153$ & 46.0 & 24.4 & $6.20-51.3$ & 43.2 & 20.4 & $0.726-6.40$ & 0.854 & 1.47 \\
\hline Endrin & ND-14.1 & 8.03 & 4.34 & ND-6.11 & 4.58 & 1.47 & $0.0438-0.513$ & 0.0614 & 0.148 \\
\hline Nitrofen & ND-2.28 & 1.30 & 0.35 & ND-8.28 & 3.33 & 2.75 & $0.0094-0.0425$ & 0.0185 & 0.0095 \\
\hline Endosulfan II & ND-12.2 & 0.67 & 2.24 & ND-5.24 & 14.2 & 1.08 & $0.00825-0.35$ & 0.184 & 0.310 \\
\hline$p, p^{\prime}-\mathrm{DDD}$ & ND-2.14 & 0.56 & 1.60 & ND-6.89 & 3.19 & 1.95 & ND-0.0742 & 0.0425 & 0.0128 \\
\hline$o, p^{\prime}-\mathrm{DDT}$ & $4.14-161$ & 35.2 & 29.1 & ND-47.5 & 40.5 & 10.4 & 2.92-9.61 & 3.31 & 1.34 \\
\hline Endrin aldehyde & ND-5.00 & 1.45 & 0.71 & $6.6-24.5$ & 18.6 & 6.61 & $0.0366-0.147$ & 0.0684 & 0.0384 \\
\hline Endosulfan sulfate & $4.65-51.4$ & 22.6 & 12.4 & $58.4-195$ & 138.4 & 50.8 & $0.0484-1.05$ & 0.458 & 0.108 \\
\hline$p, p^{\prime}$-DDT & ND-30.0 & 11.4 & 5.16 & ND-577 & 42.8 & 166 & $0.525-1.18$ & 1.09 & 0.201 \\
\hline Methoxychlor & ND-21.6 & 4.07 & 3.65 & ND-67.3 & 29.3 & 18.8 & $0.0354-0.352$ & 0.0882 & 0.0626 \\
\hline Cypermethrin & ND-1.89 & 1.25 & 0.20 & ND-8.87 & 3.18 & 2.94 & ND-0.00877 & 0.0035 & 0.0019 \\
\hline Denvalerate & ND-3.22 & 2.30 & 0.58 & ND-26.3 & 6.32 & 5.54 & $0.0454-0.158$ & 0.0703 & 0.0319 \\
\hline Deltamethrin & ND-6.28 & 4.30 & 1.32 & ND-54.2 & 31.8 & 14.5 & $0.0786-0.301$ & 0.0814 & 0.108 \\
\hline$\Sigma \mathrm{OCPs}$ & $29.6-795$ & 253 & 179 & $235-2320$ & 576 & 588.6 & 7.17-33.6 & 10.3 & 7.64 \\
\hline
\end{tabular}

ND, not detected; HCB, hexachlorobenzene; HEPO, heptachlor epoxide; OCPs, organochlorine pesticides.

ments they tend to strongly adsorb to sediments (US EPA 1999). They were frequently found in water and sediments from GTR. This reflects the abundant current use of them in the area and the river watersheds. Among cypermethrin, deltamethrin, and fenvalerate, deltamethrin had the highest concentration but cypermethrin was most frequently found in the water and sediment samples from GTR.

Pesticide concentrations in surface water (ng/l) from GTR were compared with pesticide levels in the US Environmental Protection Agency (EPA) freshwater-quality criteria for aquatic organisms and Chinese environmental quality standards for potable water supply sources (see Table 4). Pesticide concentrations were much lower than the levels in the US Environmental Protection Agency (EPA) freshwater-quality criteria for aquatic organisms or Chinese environmental quality standards for potable water supply sources with the exception that there are higher values of DDT (46.6 ng/1), chlordane $(10.1 \mathrm{ng} / \mathrm{l})$, and HEPO $(4.1 \mathrm{ng} / 1)$ than EPA chronic criteria for DDT (1 ng/l), chlordane (4.3 ng/l), and HEPO (3.8 $\mathrm{ng} / \mathrm{l})$. The results show that the water pollution of GTR and its tributaries with some pesticides is moderate for surface water. However, due to the potential endocrine-disrupting effects and the bioconcentration effects of these pesticides even at trace concentrations in water, regular monitoring is needed to manage the environmental hazards.

Due to the analytical restrictions, many pesticides (e.g., atrazine, 2,4-D, diazinon, malathion) could not be covered by our monitoring study, although some of them were also frequently used in the study area and were also identified as suspected endocrine disrupters (Ren and Jiang 2001; Crain and Guillette 1998; Laura et al. 2005; Dutta et al. 1993). Further monitoring studies that can screen more endocrine-disrupting are needed to understand and assess fully the contamination status of suspected endocrine-disrupting pesticides in the studied area.

\section{Composition Ratio of Pesticide Residues in Water and Sediment Samples from the Reservoir}

Among the analyzed pesticides, $p, p^{\prime}$-DDE, $o, p^{\prime}$-DOT, $\beta$-HCH, $\gamma-\mathrm{HCH}$, endosulfan sulfate, and aldrin were the most abundant pesticides in water while $p, p^{\prime}$-DDT, $\delta$-HCH, $\beta-\mathrm{HCH}, p, p^{\prime}$ DDE, $p, p^{\prime}$-DDT, and endosulfan sulfate were the most abun- 
Table 4. Comparison of concentrations (ng/l) of pesticides in surface water from GTR with pesticide levels in EPA freshwater-quality criteria for aquatic organisms and Chinese environmental quality standards for potable water supply sources

\begin{tabular}{|c|c|c|c|c|}
\hline \multirow[b]{2}{*}{ Pesticides } & \multicolumn{2}{|c|}{$\begin{array}{l}\text { EPA freshwater quality criteria for } \\
\text { aquatic organisms }^{\text {a }}\end{array}$} & \multirow{2}{*}{$\begin{array}{l}\text { **SEPA environmental } \\
\text { quality standards for } \\
\text { potable water supply sources }\end{array}$} & \multirow{2}{*}{$\begin{array}{l}\text { Concentrations of } \\
\text { pesticides in GTR }\end{array}$} \\
\hline & Acute criteria & Chronic criteria & & \\
\hline Bexachlorobenzene & 6000 & 3680 & 50000 & 12.4 \\
\hline Lindane & 2000 & 80 & 2000 & 31.3 \\
\hline Heptachlor & 520 & 3.8 & - & 0.98 \\
\hline Chlorpyriphos & 83 & 41 & - & 1.50 \\
\hline Heptachlor epoxide & 520 & 3.8 & 200 & 4.10 \\
\hline Chlordane & 2400 & 4.3 & - & 10.1 \\
\hline Endosulfan I & 220 & 6.5 & - & 1.48 \\
\hline Dieldrin & 359.5 & 65.1 & - & 0.59 \\
\hline Endrin & 190 & 61 & - & 8.03 \\
\hline Endosulfan II & 220 & 6.5 & - & 0.67 \\
\hline DDT & 1100 & 1 & 1,000 & 46.6 \\
\hline Methoxychlor & - & 30 & - & 4.07 \\
\hline Deltamethrin & - & - & 20,000 & 4.30 \\
\hline
\end{tabular}

EPA, US Environmental Protection Agency; SEPA, State Environmental Protection Administration of China; GTR, GuanTing reservoir; -, no data available. Acute criteria is the highest concentration of a pollutant that freshwater aquatic organisms can be exposed to for a short period ( $1 \mathrm{~h}$ ) without deleterious effects. Chronic criteria is the concentration of a chemical that is lower than chronic toxicity values for $95 \%$ of the genera that have been chronic-toxicity tested.

${ }^{a}$ Data are summarized from Nowell and Resek (1994).

${ }^{\mathrm{b}}$ Data are summarized from SEPA (2002).

dant in sediment, and $p, p^{\prime}$-DDT, aldrin, endosulfan sulfate, $\delta$ $\mathrm{HCH}, \beta-\mathrm{HCH}$, and $p, p^{\prime}-\mathrm{DDE}$ were the most abundant in pore water. In comparison with results from the Beijing Tonghui River (Zhang et al. 2004), $\alpha-\mathrm{HCH}, \delta-\mathrm{HCH}$, heptachlor, endosulfan II, and DDT were the major pesticides in water while heptachlor, dieldrin, and DDE composed $95 \%$ of the total pesticides in sediment in Tonghui River.

Figure 2 showed the composition ratios of pesticide residues in water, pore water, and sediment from the reservoir. The composition ratio values were calculated from the mean concentrations of all samples. Among $\Sigma \mathrm{HCH}(\alpha-\mathrm{HCH}+\beta-\mathrm{HCH}+$ $\gamma-\mathrm{HCH}+\delta-\mathrm{HCH}), \Sigma$ cyclodiene (the sum of amount of aldrin, dieldrin, endrin, endosulfan I, endosulfan II, and endosulfan sulfate), $\Sigma$ DDT ( $p, p^{\prime}$-DDT + o, $p^{\prime}$-DDT + p, $p^{\prime}$-DDE $+p, p^{\prime}$ DDT + methoxychlor), $\Sigma$ chlordane $(\alpha-\& \gamma-)$, and the other selected pesticides (a sum of the other selected pesticides including HCB, heptachlor, endrin aldehyde, HEPO, dicofol, acetochlor, alachlor, metolachlor, chlorpyriphos, nitrofen, trifluralin, cypermethrin, fenvalerate and deltamethrin), $\Sigma$ DDT has the highest ratio in sediment, and $\Sigma$ cyclodiene has the highest ratio in pore water, while the other selected pesticides have the highest ratio in pore water. This could be explained by the difference of those pesticides in properties such as water solubility, vapor pressure, stability, and permanence to microbial degradation. OCPs are the major pesticides whether in surface water, pore water, or in sediments (see right bar in Fig. 2). The lowest ratio of non-OCPs in sediments (higher ratio in surface water) indicated that some pesticides could currently be in use around GTR and its tributary rivers.

The results also suggested that the concentration of pesticides in sediment was higher than that in surface water. This may be due to the fact that organic hydrophobic pollutants tend to be adsorbed in the sediments (Zhang et al. 2004).

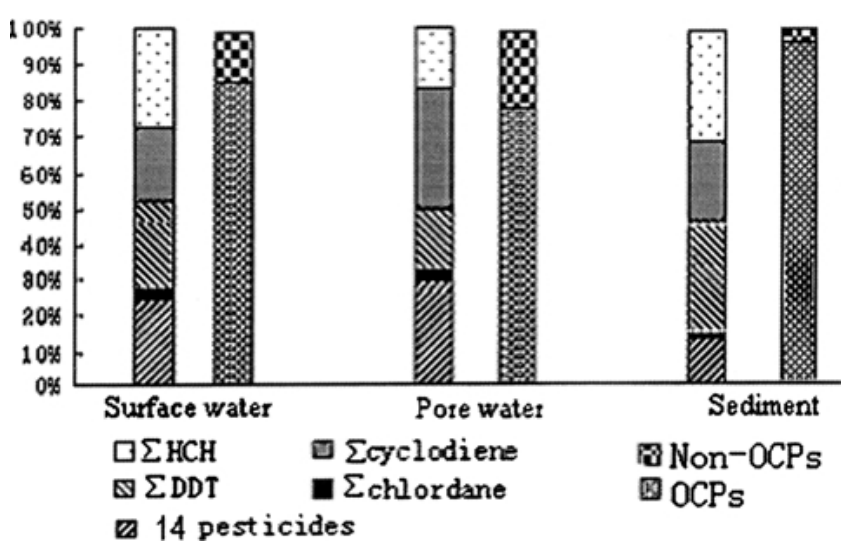

Fig. 2. Composition ratio of pesticide residues in surface water, pore water, and sediments from the reservoir

\section{Distribution, Characterization, and Seasonal Variation of Endocrine-Disrupting Pesticides in the Reservoir}

The concentrations of the pesticides detected at each of the sites are summarized for the surface water in Table 5. Among all sampling locations, higher pesticide levels appeared in site 1 (on a tributary of the reservoir near YanQing town), site 5 (situated in the center of the agricultural region), site 8 (near Guanting town), and site 9 (in front of a dam) than in other sites of GTR. The high concentrations of pesticides in water were found at two sampling locations, on two tributaries of the reservoir, in site 1 and site 5. This indicates that pesticide residues in the reservoir originate mainly from its tributaries. Among all 31 analyzed pesticides, about 20 pesticide residues 


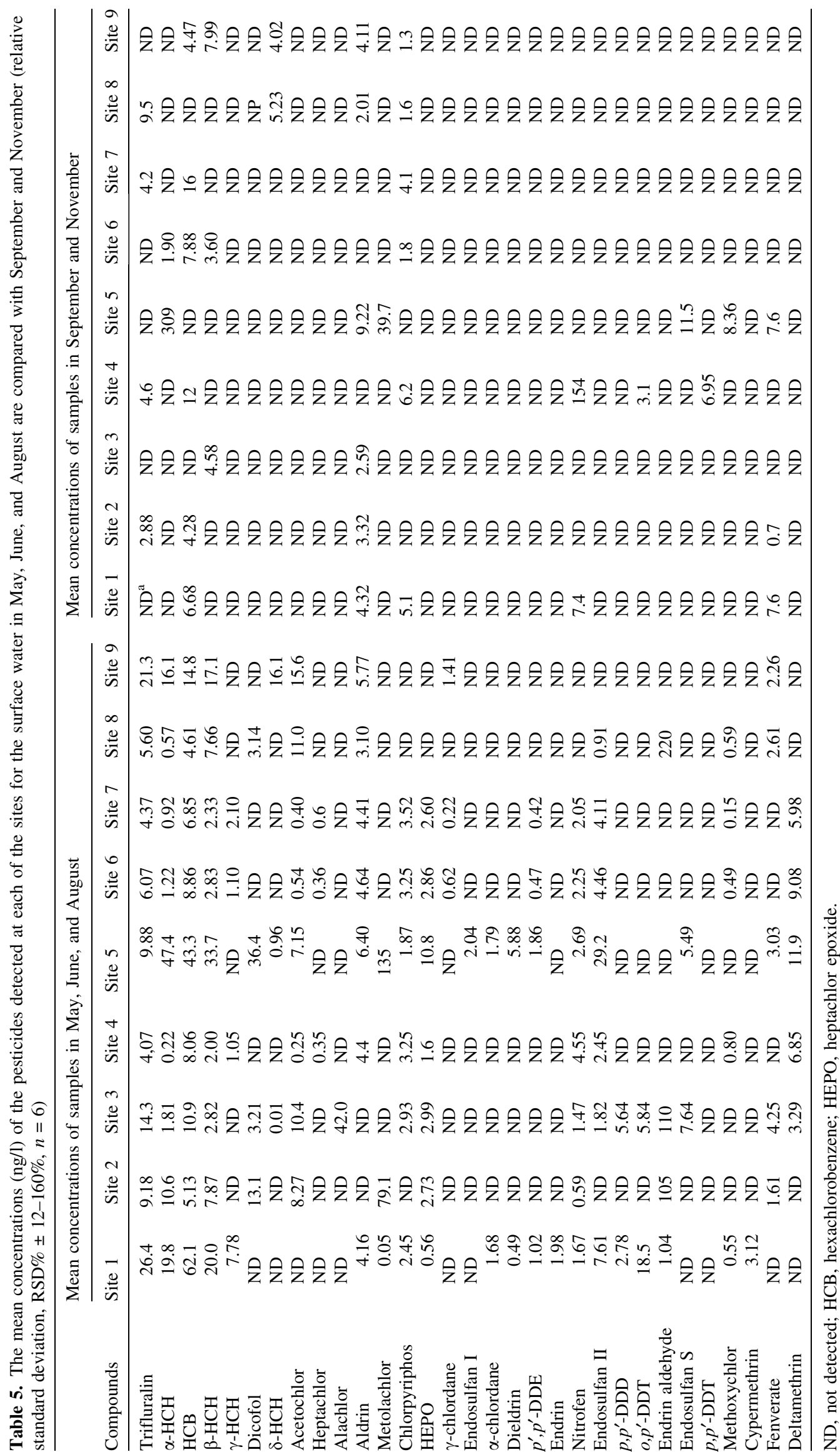


were found in water samples from the two sampling locations (site 1 and site 5). High concentrations (130 ng/l) of metolachlor in water samples from site 5 were found in summer (June 2004) and high concentrations (320 ng/l) of $\alpha-\mathrm{HCH}$ were found at site 5 in autumn (September 2003). The total residue of detected pesticides was $600 \mathrm{ng} / 1$ at site 5 in summer (June 2004). The results show that pesticides in this watershed are generally higher than the Chinese standards for tap water (500 $\mathrm{ng} / 1$ for the sum of pesticides and $100 \mathrm{ng} / \mathrm{l}$ for individual pesticides).

At least four pesticide residues were found in each water sample. Aldrin, $\mathrm{HCB}, \alpha-\mathrm{HCH}, \beta-\mathrm{HCH}$, and trifluralin were found in all sampling sites whether in water, pore water, or in sediment. All water samples had aldrin residues in the range of 2.65-34.4 ng/l; HCB, 4.43-27.3 ng/l; $\alpha-\mathrm{HCH}, 1.22-47.4 \mathrm{ng} / \mathrm{l}$; $\beta-\mathrm{HCH}, 9.33-60.5 \mathrm{ng} / \mathrm{l}$; and trifluralin, 3.41-25.2 ng/l. This indicates that the reservoir was generally polluted by the pesticides aldrin, $\mathrm{HCB}, \alpha-\mathrm{HCH}, \beta-\mathrm{HCH}$, and trifluralin. Heptachlor, $\gamma-\mathrm{HCH}$, and cypermethrin residue in water were only found in site 5. Heptachlor, $\gamma-\mathrm{HCH}$, and cypermethrin residue levels in other water samples were below the detection limit. The data from water samples are in agreement with the results of $\mathrm{HCH}$ and DDT in GTR from Wang et al. (2003). The concentrations of pesticides in water were correlated $(r=0.55$, $n=32$ ) with those in sediments taken from the same sampling sites as the water samples. There also were higher pesticide levels in sediments in site 1 , site 5 , site 8 , and site 9 than in other sites. Among all 31 analyzed pesticides, about 27 pesticide residues were found in sediment samples from the two sampling locations (site 1 and site 5). High concentrations of $\beta-\mathrm{HCH}(1.3 \mathrm{ng} / \mathrm{g}), \delta-\mathrm{HCH}(2.5 \mathrm{ng} / \mathrm{g})$, and $o, p^{\prime}$-DDT $(3.5 \mathrm{ng} / \mathrm{g})$ were found in sediment samples. The total residues of detected pesticides varied from $4.2 \mathrm{ng} / \mathrm{g}$ to $36.8 \mathrm{ng} / \mathrm{g}$, with a mean of $12.5 \mathrm{ng} / \mathrm{g}$. High concentrations of total detected residues were found in sediment samples from site 1 , site 5 , site 8 , and site 9 . Considering the higher values of organic matter (LOI, \%), clay $(\%)$ plus silt $(\%)$ in site 1 , site 5 , site 8 , site 9 , than in other sites, we can conclude that pesticides in the reservoir sediment are correlated with some factors such as LOI $(\%)$, clay $(\%)$, and silt $(\%)$. Organic matter, which influences microbial activities and variation, particularly plays a most important role in the accumulation, enrichment, or degradation of pesticides. It may be due to the fact that organic hydrophobic pollutants tend to adsorb in the sediments.

The concentrations of the pesticides detected at each of the sites for the surface water in "application season" (May, June, and August) are compared with September and November (see Table 5). Table 5 shows that the concentration of pesticides in water was generally much higher in the "application season" than in September and November. Also, more pesticide residues in the "application season" water samples were in excess of the detection limit than in September and November. On the one hand, it is likely to result that the concentration of pesticides in water was higher in the "application season" due to more agricultural operations and more pesticide application in that season. This can also explain the relatively high concentration of modern pesticides, e.g., metolachlor and nitrofen, in water and sediments in the "application season." On the other hand, more agricultural operations and activities of wildlife in water and sediment promote the diffusion of contaminants through the pores of the sedimentary layers.

\section{Possible Sources of Pesticides in GuanTing Reservoir}

The observed variation in the concentration of pesticides in water and the sediments can be expected to be caused by several factors such as the high rates of influx of contaminants into the reservoir through tributary rivers and drainage of contaminated water from the surrounding agricultural fields. The pollution might also be caused by the waste disposal from plants situated along rivers. The high total inflow of water from the rivers to the reservoir gives the accumulation of pesticides in sediments. Moreover, the diffusion of contaminants through the pores of the sedimentary layers influences the variation in concentration of various pesticides in sediments of different characteristics (Larsson et al. 1985). Also, seasonal variation in micobial growth might influence the bioirrigation of sediment resulting in an increase in mobility of various contaminants into the overlying water. In addition, another causative factor may be the relatively high concentration of pesticides in water.

Due to agricultural operations around the reservoir, the concentration of pesticides in water and sediments increases. On the one hand, new pesticides are extensively used in modern agriculture. On the other hand, agricultural operations promote diffusion of contaminants through the pores of the sedimentary layers. DDT residue levels were relatively lower than the DDE congener, indicating the lack of a recent source. The DDT compounds in sediments may be mainly derived from DDT-treated aged and weathered agricultural sources.

The frequencies of detection of aldrin compounds were $100 \%$ in sediment and $80 \%$ in water samples, respectively, which showed that the contamination of aldrin was widespread in GTR. The presence of lindane $(\mathrm{r}-\mathrm{HCH})$ is probably associated with past use of $\mathrm{HCH}$ in farms. Technical grade $\mathrm{HCH}$ consists principally of four isomers, $\alpha-\mathrm{HCH}(60-70 \%), \beta-\mathrm{HCH}$ (5-12\%), $\gamma-\mathrm{HCH}(10-15 \%)$, and $\delta-\mathrm{HCH}(6-10 \%)$ (Walker et al. 1999). Generally, the most common isomers in the environment are $\alpha-, \beta-$, and $\gamma$-isomers. But results in this study show that there were high concentrations of $\delta-\mathrm{HCH}$ in sediments in a few sampling sites. Possible reasons for the high concentration of $\delta-\mathrm{HCH}$ in sediments in the area are still unclear. Among the $\mathrm{HCH}$ isomers, $\alpha-\mathrm{HCH}$ is more likely to partition the air and be transported for long distances. Since $\alpha$ $\mathrm{HCH}$ exhibits the most carcinogenic activity among $\mathrm{HCH}$ isomers, the contamination levels detected may pose a high ecotoxicity for aquatic organisms (Doong et al. 2002). Metolachlor, deltamethrin, trifluralin, nitrofen, and acetochlor were the pesticides most frequently found in water and sediments from GTR. This reflects the abundant current use of them in the area and the river watersheds.

The highest concentrations ( $35 \mathrm{ng} / \mathrm{g}$ ) of pesticides studied were found in sediments at site 5 on May 22, 2004, and indicate that this watershed (BaHaoQiao) was the most polluted one. The pollution might be caused by the waste disposal from a wine plant situated in the region, though further survey is needed to verify this.

\section{Summary}

The analysis results showed the water pollution with pesticides is moderate in GTR and its tributaries, and a few pesticide 
residue values in a few sites are considerably high when considering the endocrine-disrupting effects and chronic health effects. Among the analyzed pesticides, $p, p^{\prime}$-DDE, $o, p^{\prime}$-DDT, $\beta-\mathrm{HCH}, \gamma-\mathrm{HCH}$, endosulfan sulfate, and aldrin were the most abundant pesticides in water while $o, p^{\prime}$-DDT, $\delta$-HCH, $\beta-\mathrm{HCH}$, $p, p^{\prime}$-DDE, $p, p^{\prime}$-DDT, and endosulfan sulfate were the most abundant in sediment.

The observed variation in the concentration of pesticides among sites is accounted for by several factors such as contaminants through the rivers and drainage of contaminated water from the surrounding agricultural fields into GTR, and the diffusion of contaminants in sediment through the pores. More agricultural operations also cause higher concentrations of pesticides in dissolved phase. Organic matter plays an important role in distribution of pesticides in an aquatic environment.

These results underscore the need to improve environmental protection measures in order to reduce the exposure of the population and aquatic biota to these endocrine-disrupting compounds. The abundant current use of the pesticides in the area should be minimized. Furthermore, regular monitoring is needed to evolve a strategy to manage the environmental hazards due to these pesticides.

Acknowledgments. This study was financially supported by the Ministry of Sciences and Technology, China (2003CB415005). The authors thank Mr. Zhe Cao and Dr. Ping Li from Agilent Technologies, Bejing Environment Lab, for helping with mass spectrometric confirmations. Professor Zouliang Jin is thanked for fruitful discussions and for his valuable comments on the manuscript. The authors thank Dr. Rongbiao Zhao, Dr. Rusong Zhao, and Dr, Yang-zhao Sun for the help of sampling on site.

\section{References}

Aguilar C, Penalver S, Pocurull E, Borrull F. Marce RM (1998) Solidphase microextraction and gas chromatography with mass spectrometric detection for the determination of pesticides in aqueous samples. J Chromatogr A 795:105-115

Albanis TA, Hela DG (1995) Multi-residue pesticide analysis in environmental water samples using solid-phase extraction discs and gas chromatography with flame thermionic and mass-selective detection. J Chromatogr A 707:283-292

Albanis TA, Hela DG, Sakellarides TM, Konstantinon IK (1998) Monitoring of pesticide residues and their metabolites in surface and underground waters of Imathia (N. Greece) by means of solid phase extraction disks and gas chromatography. J Chromatogr A 823:59-71

Albero B, Sanchez-Brunete C, Tadeo JL (2001) Multiresidue determination of pesticides in honey by matrix solid-phase dispersion and gas chromatography with electron-capture detection. J AOAC Intern 84:1165-1171

Bakan G, Kaya S, Ozkoc HB, Kurt P (1999) Certain organic pollutant levels in surface sediment of the mid Black Sea coast of Turkey MEDCOAST' 99, Antalya, Turkey, pp 455-464

Bergamaschi BA, Baston DS, Crepeau KL, Kuivila KM (1999) Determination of pesticides associated with suspended sediments in the San Joaquin river, California, USA, using gas chromatography-ion trap mass spectrometry. Toxicol Environ Chem 69:305-319

Bordet F, Inthavong D, Fremy J-M, Aspe D, Durand T, Ducher M (2002) Interlaboratory study of a multiresidue gas chromato- graphic method for determination of organochlorine and pyrethroid pesticides and polychlorobiphenyls in milk, fish, eggs, and beef fat. J AOAC Int 85:1398-1409

Boyd-Boland AA, Magdic S, Pawliszyn JB (1996) Simultaneous determination of 60 pesticides in water using solid-phase microextraction and gas chromatography-mass spectrometry. Analyst 121:929-937

Carver RE (1971) Procedures in sedimentary petrology. In: Galehouse JS (ed) Sedimentation analysis. Wiley-Interscience, New York, pp 69-92

Castilho JA, Fenzl N, Guillen SM, Nascimento FS (2000) Organochlorine and organophosphorus pesticide residues in the Atoya River basin, Chinandega, Nicaragua. Environ Pollut 110: 523-533

Castillo LE, Ruepert C, Solis E (2000) Pesticide residues in the aquatic environment of banana plantation areas in the North Atlantic Zone of Costa Rica. Environ Toxicol Chem 19:19421950

Chau ASY, Afgan BK (1982) Analysis of pesticides in water, Vol. 1: Significance, principles, techniques and chemistry of pesticides. Vol. 2: Chlorine and phosphorus-containing presticides. CRC Press Inc., Boca Raton, FL, pp 91-238

Chris HM, Brindle ID, David Hall C, Mikio Chiba (1990) Automated high-performance liquid chromatography for the determination of pesticides in water using solid phase extraction. Anal Chem 62:1495-1498

Colume A, Cardenas S, Gallego M, Valcarcel M (2001) Multiresidue screening of pesticides in fruits using an automatic solid-phase extraction system. J Agric Food Chem 49:1109-1116

Codex Alimentarius (1993) Pesticide residues in food, vol. 2 (Suppl. 1). FAO, Rome/WHO, Geneva

Colborn T, Smolen MJ (1996) Epidemiological analysis of persistent organochlorine contain- inations in cetaceans. Rev Environ Contam Toxicol 146:91-172

Crain D, Guillette L (1998) Reptiles as models of contaminant-induced endocrine disruption. Animal Reproduct Sci 53(1-4):7886

Crescenzi AC, Guerreiro O, Samperi R (1997) Development of a multiresidue method for analyzing pesticide traces in water based on solid-phase extraction and electrospray liquid chromatography mass spectrometry. Environ Sci Technol 31:479-488

Doong RA, Sun YC, Liao PL, Peng CK, Wu SC (2002) Distribution and fate of organochlorine pesticide residues in sediments from the selected rivers in Taiwan. Chemosphere 48:237-246

Dutta HM, Adihikai S, Singh NK, Roy PK, Munshi JSD (1993) Histopathological changes induced by malathion in the liver of a freshwater catfish, Heteropneustis fossilis. Bull Environ Contam Toxicol 51:895-900

Fatoki OS, Awofolu RO (2003) Methods for selective determination of persistent organochlorine pesticide residues in water and sediments by capillary gas chromatography and electron-capture detection. J Chromatogr A 983:225-236

FDEP (Florida Department of Environmental Protection) (1994) Approach to the assessment of sediment quality in Florida coastal waters, Volume I: Development and evaluation of Sediment quality assessment guidelines. MacDonald Environmental Sciences, Ltd., Ladysmith, British Columbia

Fillmann G, Readman JW, Tolosa I, Bartocci J, Villeneuve JP, Cattini C, Mee LD (2002) Persistent organochlorine residues in sediments from Black Sea. Mar Pollut Bull 44:122-133

Golterman HL, Sly PG, Thomas RL (1983) Study on the relationship between water quality and sediment transport. UNESCO, Technical Papers in Hydrology 26, France

Hakanson L, Jansson M (1983) Principles of lake sedimentology. Springer-Verlag, New York

Hemmer MJ, Hemmer BL, Bowman CJ, Krol KJ, Folmar LC, Marcovich D, Hoglund MD, Denslow ND (2001) Effects of 
p-nonylphenol, methoxychlor, and endosulfan on vitellogenin induction and expression in sheephead minnow (Cyprinodon variegatus). Environ Toxicol Chem 20(2):336-343

Hileman E (1994) Reproductive estrogens linked to reproductive abnormalities cancer. Chem Eng News (31 January):19-20

Iwata H, Tanabe S, Sakai N, Nishimura A, Tatsukawa R (1994) Geographical distribiutions of persistent organochlorines in air, water and sediments from Asia and Oceaida and their implications for global redistribution from low latitudes. Environ Pollut 85:15-33

Kelce WR, Stone CR, Law SC, Gray LE, Kemppainen JA, Wilson EM (1995) Persistent DDT metabolite $p, p^{\prime}$-DDE is a potent androgen receptor antagonist. Nature 375:581-585

Khan MAQ (1977) Pesticides in aquatic environment. Plenum Press, New York

Kobayashi H, Ohyama K, Tomiyama N, Jimbo Y, Matano O, Goto S (1993) Determination of pesticides in river water by gas chromatography-mass spectometry-selected-ion monitoring. J Chromatogr A 643:197-202

Laabs V, Amelung W, Pinto AA, Wantzen M, da Silva CJ, Zech W (2002) Pesticides in surface water, sediment, and rainfall of the Northeastern Pantanal Basin, Brazil. J Environ Qual 31(5):16361648

Lacorte S, Molina C, Barcelo D (1993) Screening of organophosphorus pesticides in environmental matrices by various gas chromatographic techniques. Anal Chim Acta 28(1):71-84

Larsson PF, Gadbois DF, Johnson C (1985) Observations on the distribution of PCBs in the deepwater sediments of the Gulf Marine. Mar Pollut Bull 16:439-442

Laura B, Maxwell, Dutta HM (2005) Diazinon-induced endocrine disruption in bluegill sunfish, Lepomis macrochirus. Ecotoxicol Environ Saf 60:21-27

MacDonald DDA (1994) Review of environmental quality criteria and guidelines for priority substances in the Fraser River basin. MacDonald Environmental Science Limited, Environmental Conservation Branch, Nanaimo, Canada

Magdic S, Pawliszyn JB (1996) Analysis of organochlorine pesticides using solid-phase microextraction. J Chromatogr A 723: $111-122$

Nerin C, Battle R, Cacho J (1998) Determination of pesticides in highwater-content samples by off-line supercritical fluid extraction gas chromatography-electron-capture detection. J Chromatogr A 795:117-124

Nogueira IMF, Sandra T, Sandra P (2004) Multiresidue screening of neutral pesticides in water samples by high performance liquid chromatography-electrospray mass spectrometry. Anal Chim Acta 502(2):209-215

Nowell LH, Resek EA (1994) National standards and guidelines for pesticides in water, sediment, and aquatic organisms: application to water-quality assessments. Rev Environ Contam Toxicol 140:1-164

Quayle CW, Jepson I, Fowlis IA (1997) Simultaneous quantitation of sixteen organochlorine pesticides in drinking waters using automated solid-phase extraction, high-volume injection, high-resolution gas chromatography. J Chromatogr A 773:271-288

Ren J, Jiang K (2001) Progress in research of endocrine-disrupting chemicals. Prog Chem 13:135-144

Sarkar A, Sen Gupta R (1991) Pesticide residues in sediments from the west coast of India. Marine Pollut Bull 22:42-45

SEPA (State Environmental Protection Administration of China) (2002) Environmental quality standard for surface water (GB383 8-2002), Beijing
Snyder JL, Robert LG, McNally ME, Oostdyk TS (1992) Comparison of supercritical fluid extraction with classical sonication and soxhlet extractions for selected pesticides. Anal Chem 64:1940-1946

Tan GH (1992) Comparison of solvent extraction and solid-phase extraction for the determination of organochlorine pesticide residues in water. Analyst 117:1129-1132

Tolosa I, Readman JW, Mee LD (1996) Method to study the separation of eight p-hydroxybenzoic esters by gas chromatography. J Chromatogr A 725:93-99

Turusov V, Rakitsky V, Tomatis L (2002) Dichlorodiphenyltrichloroethane (DDT): Ubiquity, Persistence, and Risks. Environ Health Perspect 110(2):125-128

US EPA (1984) Test Method 608, Organochlorine pesticides and PCBs, Environmental Monitoring System Laboratory, US Environmental Protection Agency, Cincinnati, $\mathrm{OH}$

US EPA, Environmental Fate and Effects Division Office of Pesticide Programs (OPPs) (1999) Sediment toxicity and fate of synthetic pyrethroids. Review of studies on partitioning, toxicity, and bioavailability of synthetic pyrethroids in sediments. January 25, 1999. Washington, DC: U.S. Environmental Protection Agency

Vassilakis I, Tsipi D, Scoullos M (1998) Determination of a variety of chemical classes of pesticides in surface and ground waters by off-line solid-phase extraction, gas chromatography with electron-capture and nitrogen-phosphorus detection, and high-performance liquid chromatography with postcolumn derivatization and fluorescence detection. J Chromatogr A 823:49-58

Wade TL, Velinsky DJ, Reinharz E, Schlekat CE (1994) Tidal river sediments in the Washington, DC area. II. Distribution and sources of organic contaminants. Estuaries 27:321-333

Walker C, Ahmed S, Brown T, Ho SM, Hodges L, Lucier G, Russo J, Weigel N, Weise T, Vandenbergh J (1999) Species, interindividual, and tissue specificity in endocrine signaling. Environ Health Perspect 107:619-624

Wan HB, Wong MK, Lim PY, Mok CY (1994) Small-scale multiresidue method for the determination of organochlorine and pyrethroid pesticides in vegetables. J Chromatogr A 662: $147-151$

Wang XT, Chu SG, Xu XB (2003) Organochlorine pesticide residues in water from Guan Ting Reservoir and Yongding River, China. Bull Environ Contam Toxicol 70:351-358

Zhan W, Xu Y, Li AH, Zhang J, Schramm KW, Kettrup A (2000) Endocrine disruption by hexochlorobenzene in crucian carp (Carrassius auratus gibelio). Bull Environ Contam Toxicol 65(5):560-566

Zhang Z, Huang J, Yu G, Hong HS (2004) Occurrence of PAHs, PCBs and organochlorine pesticides in the Tonghui River of Beijing, China. Environ Pollut 130:249-261

Zhang ZL, Hong HS, Zhou JL, Yu G, Chen WQ, Wang XH (2002a) Transport and fate of organochlorine pesticides in River Wuchuan, Southeast China. J Environ Monit 4(3):435-441

Zhang ZL, Dai MH, Hong HS, Zhou JL, Yu G (2002b) Dissolved insecticides and polychlorinated biphenyls in the Pearl River Estuary and South China Sea. J Environ Monit 4(6): 922-928

Zhang ZL, Hong HS, Wang XH, Lin JQ, Chen WQ, Xu L (2002c) Determination and load of organophosphorus and organochlorine pesticides at water from Jiulong River Estuary, China. Mar Pollut Bull 45(1-12):397-402

Zhou J, Qin Z, Cong L, Xu X (2004) Research progress of the endocrine disrupting activities of polychlorinated biphenyls. Chinese Sci Bull 49(3):215-219 